\title{
Characteristics of Unbanked Households in the Republic of Congo
}

\section{Christelle Inès Leticia Ndombi Ondze, Geslin William Ondaye, Esther Victorie Ngakoli}

Laboratoire de Recherche et d'Etudes Economiques et Sociales (LARES), Faculté des Sciences Economiques de l'Université Marien Ngouabi, Congo

Email: Christelle.ndombiondze@umng.cg, Ondaye.william@yahoo.fr, esther.ngakoli@umng.cg

How to cite this paper: Ndombi Ondze, C. I. L., Ondaye, G. W., \& Ngakoli, E. V. (2022). Characteristics of Unbanked Households in the Republic of Congo. Theoretical Economics Letters, 12, 6-18. https://doi.org/10.4236/tel.2022.121002

Received: November 29, 2021

Accepted: January 16, 2022

Published: January 19, 2022

Copyright (C) 2022 by author(s) and Scientific Research Publishing Inc. This work is licensed under the Creative Commons Attribution International License (CC BY 4.0).

http://creativecommons.org/licenses/by/4.0/

\section{(c) (i) Open Access}

\begin{abstract}
The objective of this article is to highlight the characteristics of unbanked households in the Republic of Congo. Starting from the Binomial Logit model based on data from the survey conducted by the National Credit Council (2015), the results show that age, gender, marital status, average income, holding an account with mobile money services, socio-professional category, type of employer are categories whose characteristics help define the profile of unbanked households in the Republic of Congo. Based on the results obtained, we can define the profile of an unbanked household in the Republic of Congo as follows: the unbanked Congolese household is most likely female, under 35 years of age, unmarried, does not have an account with mobile money services, is not a manager, works in the public sector and has an average income of less than 150,000 CFA francs. We recommend the public authorities to expand the device "payment of wages by bank account" to the private sector.
\end{abstract}

\section{Keywords}

Unbanked Household, Banking, Households, Binomial Logit Model

\section{Introduction}

"Globally, about 1.7 billion adults remain unbanked-without an account at a financial institution or through a mobile money provider. In 2014, that number was 2 billion (Demirgüç-Kunt et al., 2018).” Thus, unbankedness is a major concern for governments and represents a handicap both for households and for the process of financial inclusion (better access and more intensive use of financial services). For this reason, understanding the characteristics of unbanked households is of paramount importance, as it allows targeting the necessary pol- 
icies to be put in place to promote financial inclusion (Hayashi \& Minhas, 2018) and fight against unbanking. And thus, consequently, fight against social exclusion (taking into account the social role that banks play); poverty and inequality (by offering all households the possibility of financing their project via bank credit); fight against hoarding and the development of the informal economy thus mobilizing savings and relocating them towards the productive economy.

Indeed, the phenomenon of non-banking concerns all regions of the world, but to different degrees. This has given rise to reflections on the part of both politicians and researchers. For politicians, in this case the World Bank (2020), not having a bank account is a major handicap. As for researchers, their contributions range from theory to empiricism.

From a theoretical point of view, the debate on non-banking can be based on two theories, namely: the theory of the frontiers of access possibilities, which puts forward factors related to the different reasons put forward by both banks and households to explain the difficulty of accessing and using banking services (Beck \& De La Tore, 2006); the theory of barriers to access, which highlights both factors related to the profile of unbanked households and factors related to the reasons they give for not having a bank account (Leyshon \& Thrift, 1995).

Empirically, work by Hayashi and Minhas (2018) has shown that several socioeconomic factors related to household profile such as education, age, race, occupational status, and technology contribute to the likelihood of being unbanked for low-income households. While the work of Prescott and Tattar (1999) has shown that the reasons given by unbanked households to justify their status range from low-cost alternatives to holding an account for their payment service. However, Hogarth et al. (2004) put the first two perceptions into perspective and point out that several factors defining the profile of unbanked households can also be applied to the reasons for not having a bank account.

International unbanking statistics show that $31 \%$ of adults do not have a bank account. This percentage is very low in developed countries (6\%) compared to $37 \%$ in developing countries. In Congo, the unbanked rate is very high at $74 \%$, compared to the global average of $31 \%$, (Demirgüç-Kunt et al., 2018). Moreover, there are few empirical studies in the Republic of Congo on the issue of unbankedness. With the exception of some studies on financial inclusion (CNC, 2015; Batila, 2021; Aymar \& Fabrice-Gilles, 2021). In this study, we are interessed on the characteristics of unbanked households, where most research in the issue of unbankedness focused on the determinants of unbanked households globally (as we know, the determinants of unbanked households include the characteristics of unbanked household and also the reason of being unbanked household).

From the above, it is clear that the issue of non-banking is relevant in the Republic of Congo where, despite the expansion of the banking system and the implementation of several measures likely to promote banking, the use of bank ac- 
counts remains limited. Indeed, between 2005 and 2014, the number of banks increased from 4 to 10 , the number of bank branches increased ninefold, or 90 bank branches, the number of ATMs from 11 to 102 (CNC, 2015). Also, following the example of BSCA and UBA, some banks offer basic banking products at very reasonable prices, i.e. zero CFA francs as account opening fees for UBA and 2000 CFA francs for BSCA.

Taking this reality into account, we ask the following question: what are the characteristics of unbanked households in the Republic of Congo? Thus, our objective in this work is to highlight the characteristics of unbanked households, and consequently to build a profile of unbanked households. We support the hypothesis that income level, education level, age and gender are categories whose characteristics make it possible to define the profile of unbanked households in the Republic of Congo.

Apart from the introduction, our work is structured around four sections. The first section deals with the literature review, the second section presents the methodology, and the third section deals with the presentation and interpretation of the results. The fourth section is devoted to the conclusion and policy implications.

\section{Review of the Literature}

In this part of our work, we highlight the theoretical and empirical frameworks on the characteristics of unbanked households.

The theoretical framework is divided into two groups. In the first group, the idea is that unbanked households are characterized by the different reasons they give for their status. These reasons range from socio-economic and institutional factors (transaction costs of savings-related services, income level, cultural barriers, financial illiteracy, etc.). This idea is shared by Beck and De La Torre (2006) through the possibility frontier theory, which analyzes the difficulties of accessing and using banking services based on the economic principle of supply and demand.

In the second group, however, it is the profile of unbanked households that is highlighted. The unbanked households are characterized according to the profile on the basis of factors such as income, age, gender, forms of employment, psychological and cultural reasons (etc.). This idea is shared by several authors, including Leyshon and Thrift (1995) through the theory of barriers to access (which highlights factors related to the profile of unbanked households as well as the reasons given by households to justify their unbanked status).

As regards the empirical framework, several studies have been conducted on the characteristics of unbanked households. They have been approached either from the perspective of profiles and/or from the perspective of the reasons given by unbanked households to justify their status.

Thus, from a profile perspective, authors Hayashi and Minhas (2018) estimated the Probit Binomial model (the binomial probit estimation model) based 
on data from the 2015 Federal Deposit Insurance Corporation (FDIC) survey in the United States to identify, in addition to income, characteristics associated with being unbanked. It shows that low income (in particular, income below $\$ 15,000)$ has a strong independent relationship with the probability of being unbanked. In addition, several socioeconomic factors such as education, age, race, employment status, and technology contribute to the probability of being unbanked for low-income households. With respect to technology factors, they showed that low-income households without internet access have a high probability of being unbanked compared to those with internet access.

Similarly, the study by Hogarth, Anguelov, Mac and Lee (2005) presents similar results. They used the logistic regression model with SAS on data from the Federal Reserve Board's 1989, 1992, 1995, 1998, and 2001 Survey of Consumer Finances (SCF) to explore the characteristics that affect bank account ownership. Specifically, focusing on the effects that change over time may have had in bringing low- to moderate-income families into the financial system. The results reveal that increases over time were found across (the range of) income characteristics, net worth, race, education, and age. Changes over time also led to a decrease in the number of unbanked households, and the effects of these changes appear to be widespread.

Still on the theme of profiles, some authors have focused on the immigrant population and obtained similar results. As in Rhine and Greene (2006), they estimated random-effects binary choice models using SIPP (Survey of Income and Program Participation) data covering the period 1996 to 2000 to identify attributes that influence the probability of immigrants being unbanked. Their study found that the likelihood of being unbanked is high for immigrants with low education, low income, or large families; but the likelihood is low for immigrants with high wealth, high income, or married. Within immigrant groups, the probability of being unbanked is higher for Mexican and other Latino immigrants than for European and Asian immigrants.

The same is true of the study by Joassart-Marcelli and Stephens (2010) focusing on the relationship between immigrant settlement patterns and access to different financial institutions in the Greater Boston area. The analysis reveals significant differences among the 10 broad immigrant groups, with the poorest and most isolated immigrants disproportionately exposed to less formal types of financial institutions. They found that race, class and immigration interact with neighborhood level to shape access to banks and other financial services leading to a diverse financial ecology.

On the other hand, in terms of the reasons given by households for not having a bank account, the authors Prescott and Tattar (1999), using focus group interviews in the United States, sought to understand the reasons why many low-income households do not have a bank account. The results of this work showed that most unbanked households have low-cost alternatives to account ownership for their payment services. They also found that a small fraction of the population 
forget about bank accounts because their creditors can seize their bank account balance to pay their debt.

Also, Hogarth, Anguelov, and Lee (2004) used the SCF (Survey of Consumer Finances) surveys for the period 1989-2001 in the United States to explore the reasons why households do not hold bank accounts (especially current accounts). The reasons have changed over time, moving away from account characteristics to human capital (not being able to manage or balance an account) and institutional reasons (not showing a desire or inclination to deal with banks, which can mean that consumers are intimidated by the formalities of traditional banks, are limited by language barriers, have a strong preference for privacy (especially with respect to the confidentiality of their financial records)). In addition to socioeconomic and demographic characteristics, perceptions of time, knowledge, and household experiences were associated with different reasons for not having an account. Also, they found that reasons for not having a bank account were related to income, race/ethnicity, marital/gender status, planning horizon, education, previous account experience, and credit history.

In addition to work on the characteristics of unbanked households, other studies related to unbanking have focused on financial education, regulation, etc.

In this sense, Lyons and Scherpf (2004) focused on the impact of financial education on the behaviour of unbanked households. They used data collected from participants in the Federal Deposit Insurance Corporation's Money Smart program between May 2002 and February 2003 to examine the potential impact of financial education on the financial behaviour of unbanked economic agents in Chicago. Specifically, it is the decision to move from unbanked to banked status after completing a financial literacy program, such as Money Smart. They found that the Money Smart financial literacy program was successful in encouraging the unbanked to open an account; only a small portion of the sample reported at the end of the program that they did not intend to open an account. According to them, financial constraints play a predominant role in preventing the unbanked from opening an account; more than $70 \%$ of unbanked participants cite lack of money as a reason for not having an account.

Other authors, however, have focused on regulation. Washington (2006) used the standard difference-in-difference estimation approach using data on household banking status and demographic data from the Survey of Income and Program Participation (SIPP) to analyze the relationship between banking laws and the unbanked status of economic agents over the period 1985-2000. The results show that the lifeline legislation requiring banks to offer low-cost accounts led to a small decline, about $3 \%-4 \%$, in the fraction of low-income minority households without a bank account (thus a small increase of 3\% - 4\% in the number of low-income minority banked households), only with a substantial lag. The results also show that statistically the lifeline legislation had no impact on the number of low-income households that already had a bank account.

From this literature review, it emerges that on the theoretical level, households 
can be characterized either according to their profile and/or their reasons. On the other hand, the empirical results obtained are somewhat divergent. This discrepancy in the results is explained by the different nature of the fields of study and therefore of the household population concerned. It is therefore of the utmost importance to look at the characteristics of Congolese households.

\section{Methodology}

\subsection{Theoretical Model}

We conducted an empirical study based on the binomial Logit model. This model is appropriate for the treatment of microeconomic data; it is also often used to examine how the binary and discrete choices of individuals are related to their characteristics by specifying the probability that they choose one of the two alternatives. The choice of this model is justified not only by the qualitative binary nature of our dependent variable, but also by the nature of the data used in this work, which are microeconomic.

Indeed, the binomial logit model directly identifies the relationship between the explanatory variables and the explained variable. We build on the work of Hayashi and Minhas (2018), the latter estimated the binomial probit model to identify the characteristics associated with being unbanked for all households and for low-income households. In their model, individual households choose to be unbanked or banked and the probability of household $i$ being unbanked is regressed on household characteristics. To this end, the model equation is as follows:

$$
\left(Y_{i}=0\right)=\Phi\left(+\beta X_{i}\right),
$$

where $Y_{i}=1$ if household $i$ is unbanked and 0 otherwise. $\Phi$ is the cumulative distribution function. $X_{i}$ is the vector of household $i$ characteristics among the 8 categories of observable characteristics in our sample.

- Dependent variable: Bancarisation 1

Bancarisation 1 is the binary qualitative dependent variable in the case of our work. It takes the values 0 if the household is banked and 1 if the household is unbanked.

- Independent variables

Taking into account the existing literature and the available survey data, we defined (selected) eight independent variables that would define the profile of unbanked households, namely age (Age 1), gender, average income (Income 2), marital status (MS), level of education (NI), socio-professional status (statusSP), holding of an account with mobile money services (holdingCM) and type of employer (typeofemployer).

- Age 1: This variable corresponds to modalities age bellow 35 and age above 35. It takes the value 0 if individual concerned is age bellow 35 and the value 1 if individual concerned is age above 35 . This variable is presented in the work of Hayashi and Minhas (2018). 
- Gender: This variable corresponds to the male and female modalities. It takes the value 0 if the individual concerned is female (female) and the value 1 if the individual concerned is male (male). This variable is present in the work of Hogarth, Anguelov and Lee (2004) and refers to gender (male and female).

- Income 2: Corresponds to the average income received by the head of the household. It is divided into low average income (average income below 150,000 CFA francs) and high average income (average income above 150,000 CFA francs). It takes the value 0 if the household concerned receives an income of less than 150,000 CFA francs and the value 1 if the household concerned receives an income of more than 150,000 CFA francs. It was used in the work of Rhine and Greene (2006) and also in the work of Hayashi and Minhas (2018).

- SM: Corresponds to marital status and takes the values 0 if the head of household is unmarried (single, common-law, divorced, widowed) and 1 if the head of household is married (Hogarth, Anguelov, \& Lee, 2004).

- NI: It corresponds to the level of education (educational level) and takes the values 0 if the head of household is uneducated (no level and primary) and 1 if the head of household is educated (secondary I, secondary II, higher). This variable is present in several works (Rhine \& Greene, 2006; Hogarth, Anguelov, \& Lee, 2004; Hayashi \& Minhas, 2018).

- StatusSP: it corresponds to the socio-occupational category and takes the values 0 and 1, 0 if the head of the household concerned is non-managerial (employee, unskilled worker, laborer, employer-owner, own-account worker, apprentice, family helper) and 1 if the head of the household concerned is a manager (senior manager, middle manager, skilled worker employee). This variable was used by Hayashi and Minhas (2018).

- HoldingCM: It corresponds to holding an account with mobile money services and takes the values 0 if the household head does not hold a mobile money account and 1 if the household head holds a mobile money account.

- Type of employer: It corresponds to the type of employer, the institution for which the head of household works and takes the values 0 if the head of household works for the private sector and 1 if the household works for the State.

The empirical model is as follows:

$$
\begin{aligned}
\text { Bancarisation }= & a_{0}+a_{1} \text { Age }+a_{2} \text { Gender }+a_{3} \text { Income } 2+a_{4} \mathrm{SM}+a_{5} \mathrm{NI} \\
& +a_{6} \text { Status SP }+a_{7} \text { Holding } \mathrm{CM}+a_{8} \text { Type of employer }+\varepsilon
\end{aligned}
$$

\subsection{Data}

In this work, the data used are from the financial inclusion survey conducted by the CNC (National Credit Council) in the Republic of Congo (2015) with a sample of 1912 individuals. We chose to work on the data from this survey because one of its objectives "to determine a profile of the typical consumer of the unbanked population" corresponds with the objective of our work. 


\subsection{Descriptive Statistical Analyses}

The analyses of the descriptive statistics are presented in Table 1.

Table 1 presents the descriptive statistics. From this table, information on the characteristics of the sample reveals that the sample is dominated by unbanked households (83.34\%). More than half of the individuals surveyed are over 35 years old $(54.24 \%)$ and the female gender $(50.63 \%)$ is slightly more representative compared to the male gender (49.37\%). Married individuals represent $84.94 \%$ of the sample. In addition, $65.79 \%$ of the individuals surveyed have an average monthly income of more than 150,000 CFA francs. Educated households represent $81.12 \%$ of the sample. In this sample, non-managers are slightly more representative $(56.56 \%)$ than managers $(43.44 \%)$. The majority of households surveyed do not have a mobile money account $(85.81 \%)$ and are employed in the private sector $(78.61 \%)$.

Table 1. Descriptive statistics of qualitative variables.

\begin{tabular}{|c|c|c|c|}
\hline Variables & Modalités & Fréquence $^{1}$ & Pourcentage \\
\hline \multirow{2}{*}{ Bancarisation 1} & Unbanked & 1466 & 83.34 \\
\hline & Banked & 293 & 16.66 \\
\hline \multirow{2}{*}{ Age 1} & Age bellow 35 & 875 & 45.76 \\
\hline & Age above 35 & 1037 & 54.24 \\
\hline \multirow{2}{*}{ Gender } & Male & 944 & 49.37 \\
\hline & Female & 968 & 50.63 \\
\hline \multirow{2}{*}{ SM } & Unmarried & 1624 & 84.94 \\
\hline & Married & 288 & 15.06 \\
\hline \multirow{2}{*}{ Revenu 2} & Low average income $<150.000 \mathrm{~F}$ CFA & 654 & 34.21 \\
\hline & High average income $>150.000 \mathrm{~F}$ CFA & 1258 & 65.79 \\
\hline \multirow{2}{*}{ NI } & Uneducated & 361 & 18.88 \\
\hline & Educated & 1551 & 81.12 \\
\hline \multirow{2}{*}{ Statut SP } & Non managerial & 772 & 56.56 \\
\hline & Manager & 593 & 43.44 \\
\hline \multirow{3}{*}{ Détention CM } & Household: & & \\
\hline & Does not hold a mobile money account & 986 & 85.81 \\
\hline & Holds a mobile money account & 163 & 14.19 \\
\hline \multirow{2}{*}{$\begin{array}{l}\text { Type of } \\
\text { employer }\end{array}$} & Private & 1073 & 78.61 \\
\hline & Public & 292 & 21.39 \\
\hline
\end{tabular}

Source: the author using data from the CNC, 2015.

${ }^{1}$ For some variables, as Bancarisation, Detention CM, Statut SP and type of employer, the sum of frequence for each modalities is less than 1912 (which is the size of ours ample). It can be eplained by the fact that some individuals interviewers did not answer completely the survey. 


\section{Presentation and Interpretation of Results}

In this section, we present and interpret the results of the Binomial Logit estimates on the characteristics of unbanked households in the Republic of Congo.

The econometric analysis presented in Table 2 above shows that the Log pseudo likelihood value in absolute value is large (395.39272). This means that

Table 2. Binomial Logit estimation results.

\begin{tabular}{|c|c|c|}
\hline Variables & Coefficients & Effets marginaux \\
\hline \multicolumn{3}{|l|}{ Age 1} \\
\hline Age $<35$ ans réf. & $-0.6523909^{* * *}$ & $-0.1037417^{\star * *}$ \\
\hline Age $>35$ ans & $(0.2089413)$ & $(0.03157)$ \\
\hline \multicolumn{3}{|l|}{ Gender } \\
\hline Male & $-0.4983278^{\star \star}$ & $-0.0796914^{\star *}$ \\
\hline Female réf. & $(0.1984258)$ & $(0.03054)$ \\
\hline \multicolumn{3}{|l|}{ SM } \\
\hline Married & $-1.218083^{\star * *}$ & $-0.2436583^{\star \star \star}$ \\
\hline Unmarried réf. & $(0.2179546)$ & $(0.04936)$ \\
\hline \multicolumn{3}{|l|}{ Income 2} \\
\hline Low average income $<150.000$ réf. & $-0.4589753^{\star *}$ & $-0.072675^{\star *}$ \\
\hline High average income $>150.000$ & $(0.2126851)$ & $(0.03213)$ \\
\hline \multicolumn{3}{|l|}{ NI } \\
\hline Uneducated réf. & 0.2849377 & 0.0502312 \\
\hline Educated & $(0.3481305)$ & $(0.06519)$ \\
\hline \multicolumn{3}{|l|}{ Détention CM } \\
\hline Does not hold a mobile money account réf. & $-1.007488^{\star * *}$ & $-0.1988268^{\star \star \star}$ \\
\hline Holds a mobile money account & $(0.2337418)$ & $(0.05212)$ \\
\hline \multicolumn{3}{|l|}{ Status SP } \\
\hline Non managerial réf. & $-0.7814857^{\star * *}$ & $-0.1266115^{\star * *}$ \\
\hline Manager & $(0.2219069)$ & $(0.03455)$ \\
\hline \multicolumn{3}{|l|}{ Type of employeur } \\
\hline Privé réf. & $-1.188201^{\star \star \star}$ & $-0.2251458^{\star \star \star}$ \\
\hline Public & $(0.2032313)$ & $(0.0429)$ \\
\hline Cons & $\begin{array}{c}3.157021^{* * *} \\
(3961539)\end{array}$ & \\
\hline \multicolumn{3}{|l|}{ Number of obs $=887$} \\
\hline \multicolumn{3}{|l|}{$\operatorname{LR} \operatorname{chi} 2(8)=240.94$} \\
\hline \multicolumn{3}{|l|}{ Prob $>$ chi $2=0.0000$} \\
\hline Pseudo R2 $=0.2335$ & & \\
\hline Log pseudo likelihood $=-395.39272$ & & \\
\hline
\end{tabular}

The significance levels used are $1 \%\left({ }^{* *}\right), 5 \%\left({ }^{* *}\right)$ and $10 \%\left({ }^{*}\right)$ respectively. 
the data are consistent with the model used. The probability associated with chi 2 is less than $1 \%$, which leads to the conclusion that overall the explanatory variables are related to the explained variable. Finally, the Wald test shows the extent to which the set of explanatory variables influences the explained variable.

The classification test in the appendix, which allows us to understand the explanatory power of the model, shows that the percentage of prediction from the Logit Binomial model is $77.45 \%$. Regarding the discriminatory power of the model, the ROC curve (graph in appendix) shows that there is a good discrimination since the area below the curve is between 0.80 and 0.90 . This means that the model is acceptable. This means that the model is acceptable. All conditions being fulfilled, we can conclude that the model used is validated and can be interpreted.

Age, gender, marital status, income, holding an account with mobile money services, socio-professional status, and type of employer are categories whose characteristics make it possible to define the profile of unbanked households in the Republic of Congo.

The results of the study (Table 2) show that the variables age, marital status, mobile money account ownership, socio-professional status and type of employer have a negative and significant influence on non-banking at the $1 \%$ threshold. Individuals over the age of 35 have a low probability (10.3\%) of being unbanked compared to individuals under the age of 35 . This result is explained by the fact that in Congo, the labor market is heavily represented by adults compared to youth. Adults receive income (salaries, pensions) and therefore can maintain a bank account. In the Republic of Congo, youth unemployment is a concern, as more than $27 \%$ of the working population is affected (Ndinga et al., 2019).

Married households have a low probability of being unbanked (24.3\%) compared to unmarried households. This result is consistent with the results presented by Rhine and Greene (2006).

Households with a mobile money account have a low probability (19.8\%) of being unbanked compared to households without a mobile money account.

Households with the socio-professional status of manager have a low probability of being unbanked (12.6\%) compared to households with the socio-professional status of non-manager. This is explained by the fact that individuals with a low level of education are unable to understand and use banking products and services. Worldwide, $62 \%$ of unbanked households have a primary education or less, compared to about half of adults in developing economies. This share is even high in some economies such as Ethiopia, where 92\% of unbanked households have a primary education or less, and Tanzania (86\%) and Pakistan (75\%). Globally, only $38 \%$ of unbanked households have completed secondary or post-secondary education, (Demirgüç-Kunt et al., 2018).

Households that work for the government are less likely to be unbanked (22.5\%) compared to households that work in the public sector. Indeed, this result is 
consistent with the prevailing reality in the Republic of Congo where all households working for the public sector (government employees) have a bank account and receive their salaries there.

The variables gender and income 2 are significant at the 5\% level and different from zero. They have a negative influence on unbanking. All other things being equal, male households have a low probability of being unbanked (7.9\%) compared to female households. This result is consistent with the prevailing international reality. Women are overrepresented among unbanked households worldwide. Approximately 980 million women are unbanked, representing $56 \%$ of all unbanked adults worldwide. Women are also overrepresented in most economies. Similarly, this is true in economies that have successfully increased the number of account holders and have a relatively low share of unbanked adults; in this case Kenya where only one-fifth of adults are unbanked, about two-thirds of whom are women, (Demirgüç-Kunt et al., 2018).

Also, households with an income of more than 150,000 CFA francs are less likely to be unbanked (7.2\%) than households with an income of less than 150,000 CFA francs. This result is consistent with the results obtained by Hogarth, Anguelov, Mac and Lee (2005). Low-income households (income of less than 150,000 CFA francs) are not interested in having a bank account because the amount left to live on after meeting daily needs is insignificant.

\section{Conclusion and Policy Implications}

Through this study on the characteristics of unbanked households in the Republic of Congo, we conducted an empirical analysis based on the Binomial Logit model in order to highlight the characteristics of unbanked households in the Republic of Congo, and consequently, to build a profile of unbanked households. The results showed that only the level of education is not among the categories whose characteristics make it possible to define the profile of unbanked households in the Republic of Congo.

Based on the results obtained, we can define the profile of an unbanked household and say that in Congo the unbanked household is most likely to be female, under 35 years of age, unmarried, does not have an account with mobile money services, is not a manager, works in the public sector and has an average income of less than 150,000 CFA francs.

Due to a lack of data, we were not able to measure the influence of certain variables, such as knowledge of banks operating in the Congo and knowledge of the mobile money service, on non-banking.

We recommend that the public authorities extend the "payment of salaries by bank account" scheme to the private sector.

\section{Conflicts of Interest}

The authors declare no conflicts of interest regarding the publication of this paper. 


\section{References}

Aymar, G. Z. U. J., \& Fabrice-Gilles, N. A. (2021). Institutional Environment and Financial Inclusion in Sub-Saharan Africa. Modern Economy, 12, 477-494. https://doi.org/10.4236/me.2021.123025

Batila Ngouala Kombo Pierre Ghislain (2021). Analysis of the Microeconomic Factors of the Financial Inclusion of the Population in the Republic of Congo. Theoretical Economics Letters, 11, 100-115. https://doi.org/10.4236/tel.2021.111008

Beck, T., \& De la Torre, A. (2006). The Basic Analytics of Access to Financial Services $(58$ p.). Document de Travail No. 4026, Banque Mondiale. https://doi.org/10.1596/1813-9450-4026

Conseil National du Crédit (2015). Enquête sur l'Inclusion Financière en République du Congo, Rapport Final.

Demirgüç-Kunt, A., Klapper, L., Singer, D., Ansar, S., \& Hess, J. (2018). The Global Findex Database (2017): "Measuring Financial Inclusion and the Fintech Revolution”. World Bank. https://doi.org/10.1596/978-1-4648-1259-0

Hayashi, F., \& Minhas, S. (2018). Who Are the Unbanked? Characteristics beyond Income. Federal Reserve Bank of Kansas City. Second Quarter.

Hogarth, J. M., Anguelov, C. E., \& Lee, J. (2004). Why Don't Households Have a Checking Account? The Journal of Consumer Affairs, 38, 1-34. https://doi.org/10.1111/j.1745-6606.2004.tb00463.x

Hogarth, J. M., Anguelov, C. E., Mac, F. E., \& Lee, J. (2005). Who Has a Bank Account? Exploring Changes over Time, 1989-2001. Journal of Family and Economic Issues, 26, 5-28. https://doi.org/10.1007/s10834-004-1410-6

Joassart-Marcelli, P., \& Stephens, P. (2010). Immigrant Banking and Financial Exclusion in Great Boston. Journal of Economic Geography, 10, 883-912. https://doi.org/10.1093/jeg/lbp052

Leyshon, A., \& Thrift, N. (1995). Financial Exclusion and the Shifting Boundaries of the Financial System. Environment and Planning A, 28, 1150-1156.

https://doi.org/10.1068/a281150

Lyons, A. C., \& Scherpf, E. (2004). Moving from Unbanked to Banked: Evidence from the Money Smart Program. Financial Services Review, 13, 215-223.

Ndinga, M. M. A., Mampassi, J. A., \& Mboulou, S. R. (2019). Impact des politiques publiques d'emploi sur la sortie du chômage des jeunes au Congo. CRDI.

Prescott, E. S., \& Tattar, D. D. (1999). Means of Payment, Unbanked, and EFT “99”. Federal Reserve Bank of Richmond Economic Quarterly, 85, 49-70.

Rhine Sherrie, L. W., \& Greene, W. H. (2006). The Determinants of Being Unbanked for U.S. Immigrants. The Journal of Consumer Affairs, 40, 21-40. https://doi.org/10.1111/j.1745-6606.2006.00044.x

Washington, E. (2006). The Impact of Banking and Fringe Banking Regulation on the Number of Unbanked Americans. The Journal of Human Resources, 41, 106-137. https://doi.org/10.3368/jhr.XLI.1.106 


\section{Appendix}

Classification test

\begin{tabular}{|c|c|c|c|}
\hline Classified & $\mathrm{D}$ & $\sim \mathrm{D}$ & Total \\
\hline+ & 573 & 124 & 697 \\
\hline- & 76 & 114 & 190 \\
\hline Total & 649 & 238 & 887 \\
\hline
\end{tabular}

Classified + if predicted $\operatorname{Pr}(\mathrm{D}) \geq 0.5$

True $\mathrm{D}$ defined as bancarisation $1 !=0$

$\begin{array}{lll}\text { Sensitivity } & \operatorname{Pr}(+\mid \mathrm{D}) & 88.29 \% \\ \text { Specificity } & \operatorname{Pr}(-\mid \sim \mathrm{D}) & 47.90 \% \\ \text { Positive predictive value } & \operatorname{Pr}(\mathrm{D} \mid+) & 82.21 \% \\ \text { Negative predictive value } & \operatorname{Pr}(\sim \mathrm{D} \mid-) & 60.00 \%\end{array}$

$\begin{array}{lll}\text { False + rate for true } \sim \mathrm{D} & \operatorname{Pr}(+\mid \sim \mathrm{D}) & 52.10 \% \\ \text { False }- \text { rate for true D } & \operatorname{Pr}(-\mid \mathrm{D}) & 11.71 \% \\ \text { False + rate for classified }+ & \operatorname{Pr}(\sim \mathrm{D} \mid+) & 17.79 \% \\ \text { False - rate for classified - } & \operatorname{Pr}(\mathrm{D} \mid-) & 40.00 \%\end{array}$

Correctly classified $\quad 77.45 \%$

\section{Courbe ROC}

Number of observations $=887$

Area under ROC curve $=0.8234$

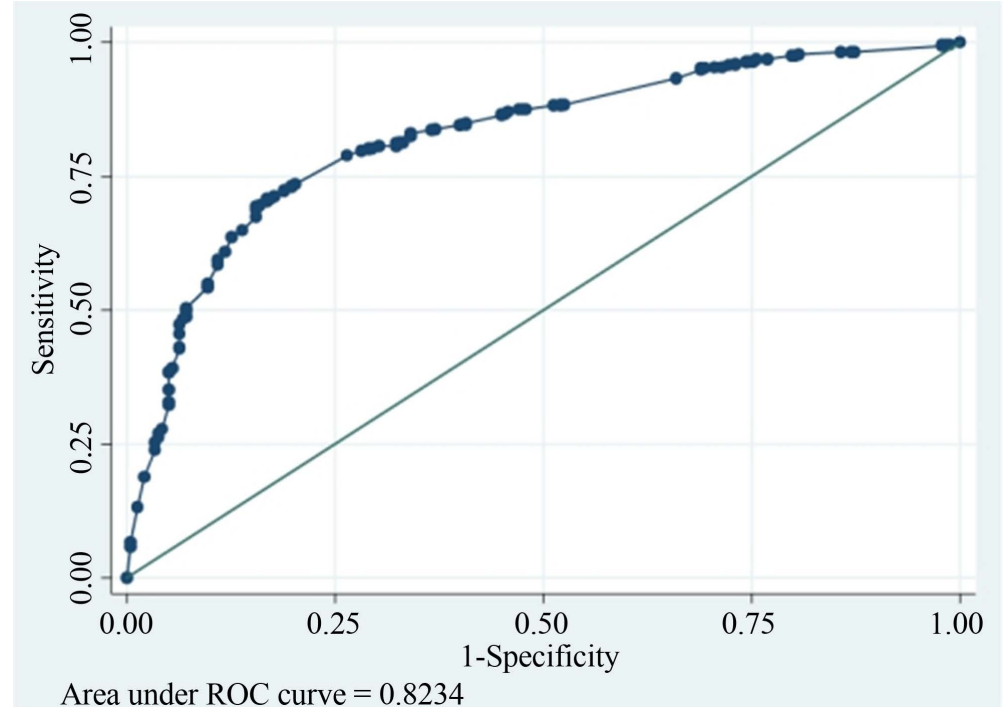

